International Journal of Agriculture, Environment and Bioresearch

Vol. 06, No. 06; 2021

ISSN: $2456-8643$

\title{
CHARACTERISATION AND BIOASSAY OF BIOFILMED HALOTOLERANT N- FIXER BIOFERTILIZERS FOR IMPROVING THE RICE SEEDLING GROWTH ON SALINIZED GROWING MEDIA
}

\author{
Fathin Rasima Daulay ${ }^{1}$, Roby Ibnu Syarifain ${ }^{1}$, Natabella Julie Hasty ${ }^{2}$, Fachri Dio Pamungkas ${ }^{2}$, Mieke \\ Rochimi Setiawati ${ }^{3}$, Kustiwa Adinata ${ }^{4}$ and Tualar Simarmata ${ }^{3}$ \\ ${ }^{1}$ Master Candidate at Agriculture Faculty of Universitas Padjadjaran, Jatinangor 45363, West Java, Indonesia. \\ ${ }^{2}$ Bachelor Candidate at Agriculture Faculty of Universitas Padjadjaran, Jatinangor 45363, West Java, Indonesia. \\ ${ }^{3}$ Department of Soil Sciences and Land Resources Management, Agriculture Faculty of Universitas Padjadjaran, \\ Jatinangor 45363, West Java, Indonesia.
}

https://doi.org/10.35410/IJAEB.2021.5691

\begin{abstract}
Salinity affects the water potential in plants and causes a devastating effect on rice growth and lead to a significant rice yield loss. The research was done to screen the halotolerant of N-fixer bacteria from saline ecosystem which capable to form the biofilm attached to roots system. Five of composite soil samples were taken from plant rhizospheres of saline ecosystems and resulted 15 bacterial isolates. Seven isolates which capable to form a biofilm were selected for bioassay using the rice seedling on salinized growing media. The experiments was arranged as randomized block design, consisted 8 treatments and provide with 3 replications. Rice seedlings were grown on salinized Fahraeus Gmedia (4 dS m-1) for 21 days on green house. The observed responds were included plant height, root length and dry weight. The experimental results showed that the bacterial isolates gave a significant effect on plant height, dry weight roots and total biomass. The highest plant height and total biomass were by the Isolates of C33 and E52 were $7.93 \mathrm{~cm}$ and $7.56 \mathrm{mg}$. The root was increased by 38, 20, and $20 \%$, respectively and total biomass was increased by 41,39 , and $64 \%$, respectively This finding concludes these promising bacterial isolate of salt tolerant biofilmed $\mathrm{N}$-fixers could develop as bioagent to alleviate the salinity stress to improve the rice growth on saline lowland rice fields.
\end{abstract}

Keywords: Salinity stress, Lowland rice, Rhizobacteria, rice growth, biofilm.

\section{INTRODUCTION}

Rice is an important commodity and staple food for Indonesia. [1] Indonesian people consume rice as the main staple food. Most Indonesian people consume rice for their carbohydrate supply. This causes a very high dependence on rice. So, rice had an important role for the Indonesian economy. The agricultural practices is forced to intensify to produce more food to meet the requirement of rapidly growing population in Indonesia. The rice consumption is about $94,9 \mathrm{~kg}$ capita- 1 year- 1 or the total need of rice is about 19,99 million tons year- 1 , while the currently rice production is about 31,33 million tons [2]. In addition, the areal of lowland rice ("known as sawah") is shrinking due the land conversion to non agricultural uses. [3] Shows that the conversion rate of paddy fields to non-rice fields is 96.512 ha year-1. Moreover, most of the rice field along the coastal areal are subjected to salinization due to the rise of sea levels and global climate change [4]. Consequently, the extent of rice cultivation on saline soils is required to increase the rice production and to secure the food security. 
The potential of saline for rice cultivation is about 0,44 millions ha and mostly situate along the coastal area [5]. High sodium content or salinity is the main constraint for rice growth and development. There are five classicicatons of saline soils based on electric conductivity including very low ( $<1 \mathrm{dS} \mathrm{m}-1)$, low (1-2 dS m-1), medium (2-3 dS m-1), high (3-4 dS m-1), and very high $(>4 \mathrm{dS}$ m-1) [6]. The effect of salinity on plants is very complicated. Salinity cause ion toxicity, osmotic and secondary stress. Excessive $\mathrm{Na}+$ ion on the surface the plant roots inhibit the absorption of $\mathrm{K}+$ by root due to lower osmotic potential [7]. Salinity impairs the crop productivity and quality seedling establishment and stunted plant growth [8].

Effort to alleviate the salinity effect on rice growth can be done by engineering rhizomicrobiome or rhizosphere through introducing or application of beneficial halotolerant $\mathrm{N}$ fixers as biofertilizers or bioagent. Biofertilizers is a efficient microbial fertilizers that give an important role to increase the rice yield productivity by biological nitrogen fixation, producing growth hormones, vitamins and other growth promoters required for plant growth [9]. Application N-fixers biofertilizers such as Azotobacter and Azospirillum inoculant contribute to the improvement of plant growth and fertilizers efficiency [10].

The latest study revealed that attached bacterial to roots hairs to thin layer of microbe, called as biofilm gain more attention for improving the ability of rice to adapt on saline ecosystem. These microbes following to biotic or abiotic surfaces that is protected from environmental stresses by a self-produced extracellular matrix [11]. The growth and yield of rice was increased by the biofilm biofertilizers inoculant [12].

This study is focused to screen the potential halotolerant rhizobacterial of biofilm N-fixer isolates through characterization and bioassay that could be developed as microbial fertilizers (biofertilizers) or bioagent for improving rice growth and productivity under saline ecosystem in sustainable ways.

\section{MATERIALS AND METHODS}

\subsection{Materials}

This research was held from July 2021 to November 2021. About $1 \mathrm{~kg}$ of composite soils samples (five subsamples) were taken from 0-20 $\mathrm{cm}$ depth using an auger soil probe from each ecosystem using. composite soil samples were taken from different ecosystems from Cimrutu Village in Patimuan District of Cilacap Regency. The location of soils sampling is shown in Table 1.

\section{Table 1. Sampling site and vegetation}

\begin{tabular}{|cccc|}
\hline Sample Code & Coordinate & Ecosystem & Vegetation \\
\hline $\mathrm{A}$ & $07^{\circ} 37^{\prime} 29.3^{\prime \prime} \mathrm{S}$ & Saline & Oryza sativa \\
& $108^{\circ} 49^{\prime} 00.3^{\prime \prime} \mathrm{E}$ & & \\
\hline $\mathrm{B}$ & $07^{\circ} 37^{\prime} 29.6^{\prime \prime} \mathrm{S}$ & Saline & Eleocharis dulcis \\
& $108^{\circ} 49^{\prime} 00.1^{\prime \prime} \mathrm{E}$ & & \\
\hline $\mathrm{C}$ & $07^{\circ} 37^{\prime} 29.1{ }^{\prime \prime} \mathrm{S}$ & Saline & Oryza sativa with \\
& $108^{\circ} 48^{\prime} 56.3^{\prime \prime} \mathrm{E}$ & & Nymphee sp. \\
\hline $\mathrm{D}$ & $07^{\circ} 37^{\prime} 29.1{ }^{\prime \prime} \mathrm{S}$ & Saline & Monochoria \\
\hline
\end{tabular}


International Journal of Agriculture, Environment and Bioresearch

Vol. 06, No. 06; 2021

ISSN: $2456-8643$

\begin{tabular}{|cccc|}
\hline & $108^{\circ} 48^{\prime} 56.3$ '” & & vaginalis \\
\hline $\mathrm{E}$ & $07^{\circ} 37^{\prime} 29.1$ 's & Saline & Cyperus iria. \\
& $108^{\circ} 48^{\prime} 56.3$ ' $\mathrm{E}$ & & \\
\hline
\end{tabular}

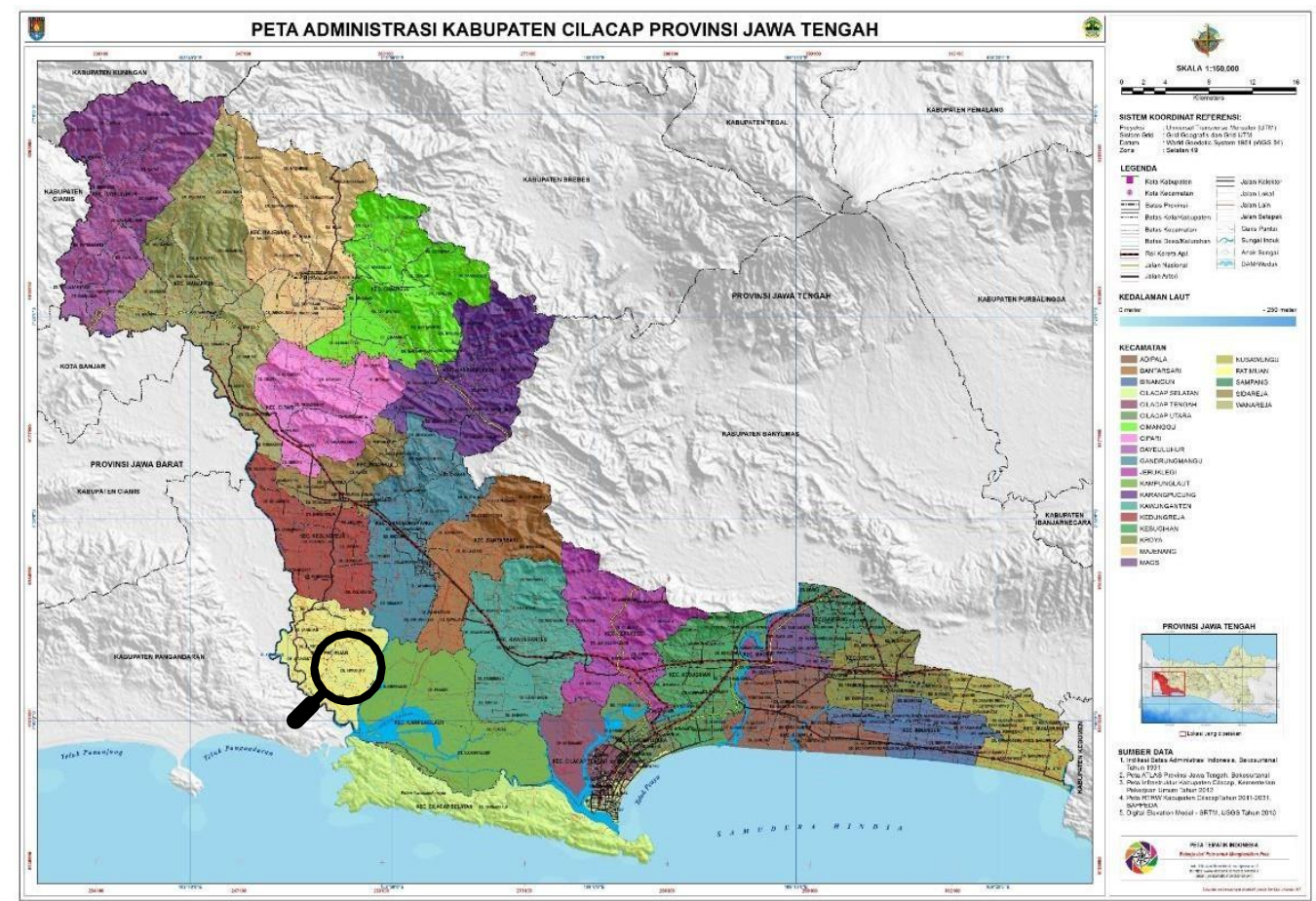


Vol. 06, No. 06; 2021

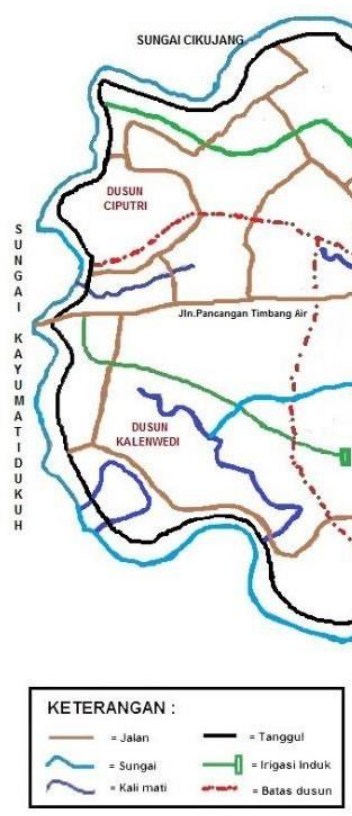

ISSN: $2456-8643$

Figure 1. Acces and location of sampling area in Cimrutu village of Cilacap

The materials to be used in this research are isolates from 5 soil samples from different ecosystems, Inpari 34 rice seeds, Ashby media, Fahraeus media saline at 4 dS m-1, aquadest, parchment paper, aluminum foil, spiritus, crystal violet, $\mathrm{NaCl}$ pro analysis, plastic wrap, cotton.

2.2. Screening of N-fixers and Purification Isolates

Screening of halotolerant N-fixer rhizobacteria (HNR) using salinized selective media of Ashby's Mannitol Nitrogen Free (Mannitol, K2HPO4, MgSO4, NaCl, K2SO4, CaCO3) were conducted at the Soil Biology Laboratory, Greenhouse, Department of Soil Science and Land Resources, Faculty of Agriculture, Universitas Padjadjaran, Jatinangor District, Sumedang Regency, West Java. The dilution method was used for the isolation of HNR. About $10 \mathrm{~g}$ of rhizosphere soil in $90 \mathrm{ml}$ of Ashby's Mannitol liquid medium and then incubated for 3 x 24 hours. At the end of incubation about $0.5 \mathrm{~cm}$ from the surface of the medium pellicle was visible. These bacteria configurate a pellicle $0.5 \mathrm{~cm}$ from the media, which will then move to the surface when nitrogen in the cell accumulates [13]. The pellicle formed on the surface of the liquid Asbhy was then grown in a Petridish containing solid Asbhy media by streaking to obtain pure isolate. Purification was done by aseptic scraping in a laminar space and was incubated for 1-2 days until new pure colonies were formed. Replanting was carried out after the pure colonies grew on the media, which was done by taking separate colonies and streaking them on the Ashby media so that pure bacteria were obtained.

\subsection{Characterization and Biofilm Test of Nitrogen-Fixing Bacteria Isolates}

The morphological observations of isolates were carried out microscopically which included the shape of the bacteria under a microscope with 1000 times magnification and the types of bacteria using the Gram staining method. According to Gram staining method, bacteria divided into 2 groups, namely Gram Positive Bacteria and Gram Negative Bacteria. The staining index is that gram-positive bacteria will be violet and gram-negative bacteria will be red. 
Biofilm test was carried out qualitatively with Microtiter Plate Assay (MPA). Preparation was carried out by inoculation of one agar isolate into the Nutrient Agar (NA) medium and biofilm analysis using liquid NA media. Biofilm staining was carried out by removing planktonic cells from the microtiter plate. Plate microtiter which giving a violet color on the walls indicates the presence of bacteria that can form biofilms. [14].

\subsection{Biological assay (Bioassay)}

Bioassay for halotolerant nitrogen-fixing rhizobacteria (HNR) using rice variety of Inpari 34 were carried out with selective media Fahraeus free nitrogen $(\mathrm{CaCl} 2, \mathrm{MgSO} 4, \mathrm{KH} 2 \mathrm{PO} 4$, $\mathrm{Na} 2 \mathrm{HPO} 4.2 \mathrm{H} 2 \mathrm{O}, \mathrm{C} 6 \mathrm{H} 5 \mathrm{FeO} 7, \mathrm{Micro}$ nutrient) [15] .This research method uses a randomized block design, consisted 8 treatments (control and seven isolates) and provide with 3 replications. The rice seeds were coated with sterile parchment paper and given sterile distilled water to be germinated in a petri dish for five days at a temperature of $30 \mathrm{oC}$. Previously, the rice seeds were sterilized using $\mathrm{HgCl} 20.2 \%$ for \pm 2 minutes and given $70 \%$ alcohol for $\pm 1-2$ minutes, then rinsed three times using distilled water. In this test, $90 \mathrm{ml}$ of salinated Fahraeus media was used which was planted in a test tube with a size of $100 \mathrm{ml}$. At the top of the tube is propped up using plastic and a pipe mouth. Observations were made including root length $(\mathrm{cm})$ and shoot length (cm) which were carried out every 4 days. Meanwhile, the root weight and Plant Dry Weight was observed on the last day of observation.

\section{RESULTS AND DISCUSSION}

\subsection{Morphology of Nitrogen-Fixing Bacteria}

The morphological and microscopically observations of fifteen isolates showed that bacterial shape belong to bacilli or cocci and the colony color is red or violet (Table 2 and Figure 2), and the qualitative capability to form the biofilm is shown in Figure 3.

Table 2. Morphological Gram staining results and biofilm test of HNR isolates

\begin{tabular}{|rcccc|}
\hline $\begin{array}{r}\text { Isolat } \\
\text { Code }\end{array}$ & $\begin{array}{c}\text { Bacterial } \\
\text { Shape }\end{array}$ & $\begin{array}{c}\text { Bacteria } \\
\text { Cells } \\
\text { Color }\end{array}$ & Gram Test & Biofilm Test \\
& & & & \\
\hline A11 & Bacil & Violet & + & - \\
A12 & Cocci & Violet & + & - \\
A13 & Bacil & Red & - & + \\
B21 & Bacil & Red & - & + \\
B22 & Bacil & Red & - & - \\
B23 & Cocci & Violet & + & - \\
C31 & Cocci & Violet & + & - \\
C32 & Cocci & Violet & + & + \\
\hline
\end{tabular}


International Journal of Agriculture, Environment and Bioresearch

Vol. 06, No. 06; 2021

ISSN: 2456-8643

\begin{tabular}{|lcccc|} 
C33 & Bacil & Red & - & + \\
D41 & Bacil & Violet & + & - \\
D42 & Cocci & Violet & + & - \\
D43 & Bacil & Red & - & + \\
E51 & Cocci & Violet & + & - \\
E52 & Bacil & Red & - & + \\
E53 & Bacil & Red & - & + \\
\hline
\end{tabular}

Table 1 shows that the seven selected isolates (A13, B21, B22, C33, D43, E52, and E53) were characterized as Azotobacter sp. The genus of Azotobacter can be characterized by gramnegative pleomorphic nature, which means that it does not have an irregular shape starting from bacil to cocci [16].

Results of Gram staining are seven isolates selected on Figure 2. 
International Journal of Agriculture, Environment and Bioresearch

Vol. 06, No. 06; 2021

ISSN: $2456-8643$
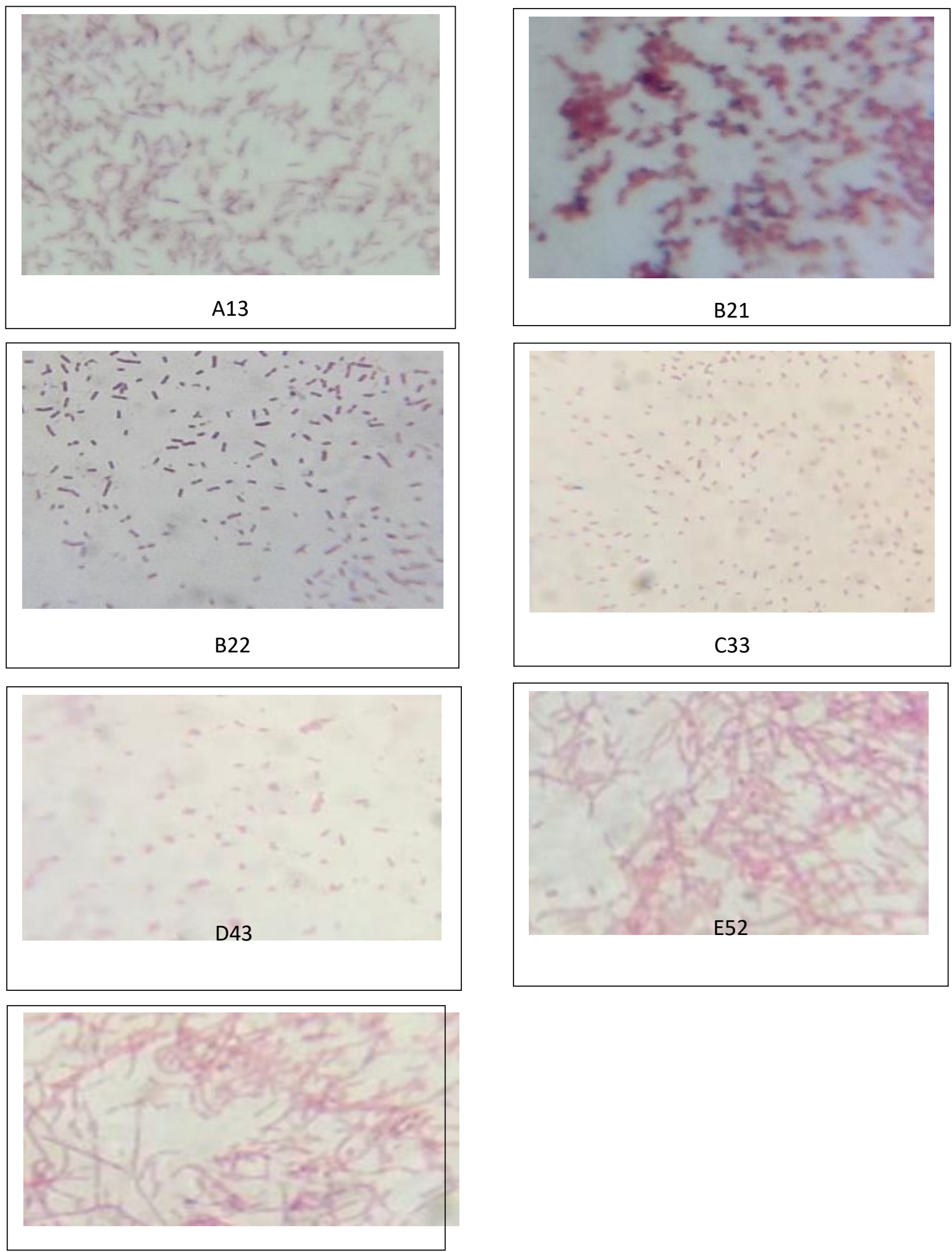
Figure 2. The Appear of bacterial isolates according gram stain

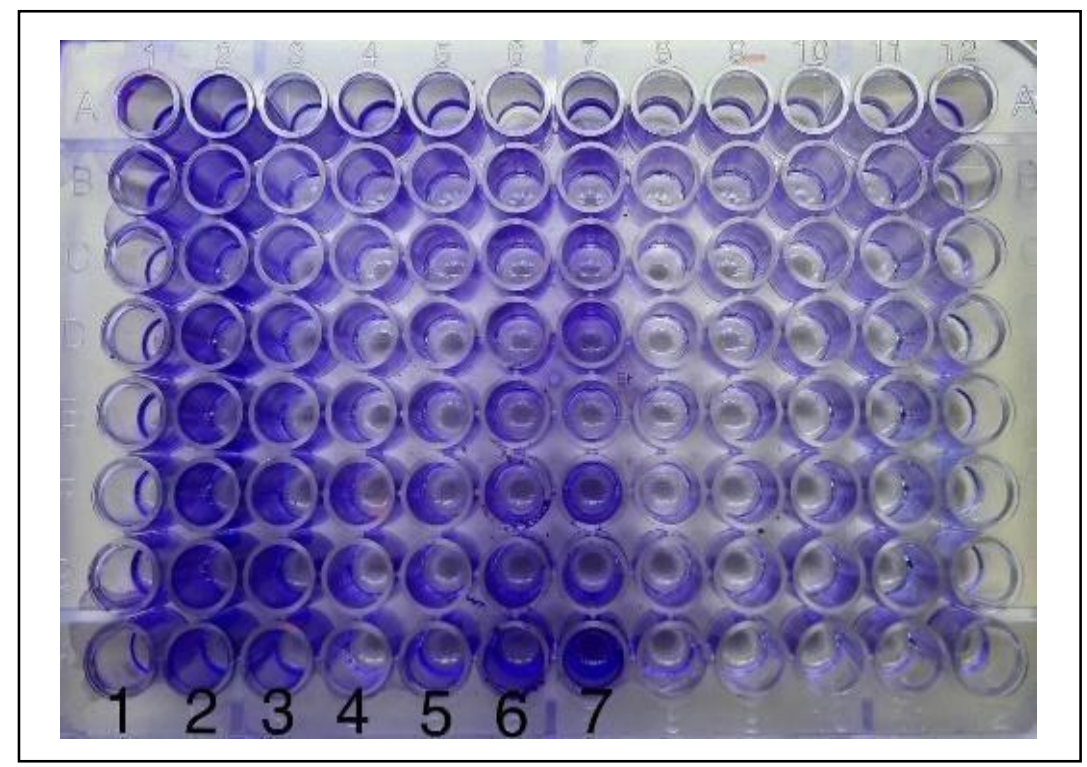

Figure 3. The qualitative capability to form the biofilm of isolate $(1=\mathrm{A} 13,2=\mathrm{B} 21,3=\mathrm{B} 22,4$ $=\mathrm{C} 33,5=\mathrm{D} 43,6=\mathrm{E} 52$, and $7=\mathrm{E} 53$ )

In Figure 3 revealed that seven bacterial isolates were able to produce biofilms which were indicated by the presence of purple dye on the walls of the microtiter plate after being stained with $0.1 \%$ crystal violet. Number 1 is isolate A13, number 2 is isolate B21, number 3 is isolate $\mathrm{B} 21$, number 4 is isolate C33, number 5 is isolate D43, number 6 is isolate E52, and number 7 is isolate E53. If an unwashed purple color is formed, the amount of bound dye is assumed to be equal to the amount of microbial biofilm in the well [14]. Biofilm formation can also be enhanced if added by amino acids [17]. Amino acids obtained from root exudates, research showed that the chemotactic effect of root exudates in the form of amino acids was able to help Azotobacter chrococcum in increasing the biofilm on the root surface [18].

\subsection{Growth Character of Rice Seedling}

The growth roots length, shoot-roots dry weigh and total biomass were significantly affected by the inoculation of HNR, while the plant height was not affected (Table 3 and Table 4). The highest roots length and root increment was given by the isolate of $\mathrm{C} 33$ and follow by the isolate D43 and E52 (figure 4). Moreover, the roots length increased by $14.16 \mathrm{~cm}, 12.36 \mathrm{~cm}$ and 12.33 $\mathrm{cm}$. Which stated that with the addition treatment of nitrogen-fixing rhizobacteria inoculants produced rice plants with thicker root conditions and higher rice plant stems than controls [19]. Nutrient-providing rhizobacteria that live in the root rhizosphere (rhizobacteria) have a role, one of which is N2 fixing and produce growth hormones such as IAA. The root was increased by 38 , 20 , and $20 \%$, respectively. 
Table 3. Effect isolate inoculation on plant height and roots length of rice seedling after 21 days on Salinized Media (4 dS m-1)

\begin{tabular}{|lccc|}
\hline \multicolumn{1}{|c}{ Selected isolate Code } & \multicolumn{2}{c|}{ 21 Days After Planting } & \\
\hline \multicolumn{1}{c}{ Plant Height $(\mathbf{c m})$} & Root Height $\mathbf{( c m )}$ & Root Increment (\%) \\
\hline Control & $6.33 \mathrm{a}$ & $10.23 \mathrm{a}$ & - \\
A13 & $7.50 \mathrm{a}$ & $11.00 \mathrm{ab}$ & 7 \\
B21 & $4.63 \mathrm{a}$ & $11.33 \mathrm{abc}$ & 11 \\
B22 & $5.56 \mathrm{a}$ & $11.43 \mathrm{abc}$ & 38 \\
C33 & $7.93 \mathrm{a}$ & $14.16 \mathrm{~d}$ & 20 \\
D43 & $6.60 \mathrm{a}$ & $12.36 \mathrm{c}$ & 20 \\
E52 & $5.86 \mathrm{a}$ & $12.33 \mathrm{c}$ & 13 \\
E53 & $6.33 \mathrm{a}$ & $11.60 \mathrm{bc}$ & \\
\hline
\end{tabular}

Note: The average value followed by the same letter in the same column shows no significant difference at the 5\% level according to Duncan's Test.

The activity of HNR on root length is shown visually in Figure 4.

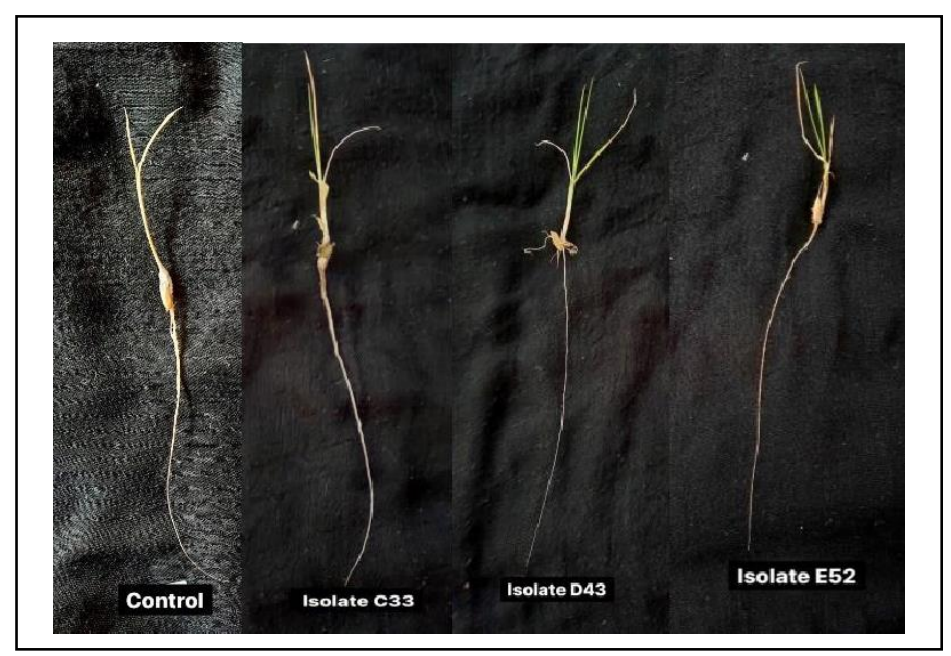

Figure 4. Shoot and roots performance of rice seedling affected by HNR isolate 
Vol. 06, No. 06; 2021

ISSN: $2456-8643$

Addition, Figure 4. This shows a significant difference between control treatment and C33,D43 and E52 isolates under saline conditions which had the highest root length among all treatments. C33, D43 and E52 isolates able to independently increase root length in saline conditions. It is suspected that $\mathrm{N}$ - fixing bacteria activity is more likely to work in secreting growth hormone IAA which has a function in root elongation. Which states that HNR is a group of bacteria that live in the rhizosphere area and act as a plant growth promoter. HNR bacteria also produce nitrogenase enzymes which function to fix nitrogen in the atmosphere and then transfer it to plants for use in metabolic processes [20].

It is clear that rice plants in saline conditions will show an impact in the form of salt stress in the form of root symptoms being short and not dense, then plant height are short and pale leaf color but the addition of $\mathrm{N}$-fixing bacteria isolates in saline media can help rice plants grow more well then the control treatment. In the control of rice plants, the results of the non-saline biological test had quite good growth, but due to the absence of the addition of N-fixing bacteria isolates, the growth of rice was not because plant growth was influenced by the availability of nutrients in the growing media. The increase in plant growth is the influence of bacteria that can change elements that are not available to be available to plants so that the control has lower growth than all treatments given HNR isolates. Plant have different various respons to salinitiy stress (salt tolerance) [21]. There are plants that could survive in high saline soil conditions and while others cannot [22].

\subsection{Shoots Dry Weight, Roots Dry Weight, and Biomass Total}

Furthermore, Table 4 show that shoot and roots dry weight and as were affected by the inoculation of HNR significantly compared to control the highest shoot dry weight was resulted by the isolate E52, while the root dry weight and total biomass were given by the isolates of C33, D43 and E53. The total biomass was increased by 41, 39, and $64 \%$, respectively.

Tabel 4. Effect of bacterial isolate inoculation on shoot-root dry weight and biomass of rice seedling 21 days on salinized media

\begin{tabular}{|ccccc|}
\hline $\begin{array}{c}\text { Isolate } \\
\text { Code }\end{array}$ & $\begin{array}{c}\text { Shoot Dry } \\
\text { Weight } \\
(\mathbf{m g})\end{array}$ & $\begin{array}{c}\text { Root Dry } \\
\text { Weight } \\
(\mathbf{m g})\end{array}$ & $\begin{array}{c}\text { Biomass } \\
\text { Total }(\mathbf{m g})\end{array}$ & $\begin{array}{c}\text { Increment } \\
(\boldsymbol{\%})\end{array}$ \\
\hline Control & $3.13 \mathrm{ab}$ & $1.46 \mathrm{a}$ & $4.6 \mathrm{ab}$ & - \\
$\mathrm{A} 13$ & $3.03 \mathrm{ab}$ & $1.36 \mathrm{a}$ & $4.4 \mathrm{a}$ & -4 \\
$\mathrm{~B} 21$ & $4.00 \mathrm{bc}$ & $1.46 \mathrm{a}$ & $5.46 \mathrm{bc}$ & 18 \\
\hline
\end{tabular}


International Journal of Agriculture, Environment and Bioresearch

Vol. 06, No. 06; 2021

ISSN: 2456-8643

\begin{tabular}{|ccccc|}
\hline B22 & $2.10 \mathrm{a}$ & $1.50 \mathrm{a}$ & $3.60 \mathrm{a}$ & - \\
$\mathrm{C} 33$ & & & \\
& & & \\
$\mathrm{D} 43$ & $4.00 \mathrm{bc}$ & $2.53 \mathrm{~b}$ & $6.53 \mathrm{c}$ & 39 \\
$\mathrm{E} 52$ & & & \\
$\mathrm{E} 53$ & $5.00 \mathrm{bc} \mathrm{d}$ & $2.40 \mathrm{~b}$ & $6.40 \mathrm{~cd}$ & 64 \\
\hline
\end{tabular}

Note: The average value followed by the same letter in the same column shows no significant difference at the 5\% level according to Duncan's Test.

Based on Table 4 it can be seen that the addition of N-Fixing bacteria isolates increased the dry weight of the dead and roots along biomass total which gave the highest results, which was found in treatment $\mathrm{G}$ with isolate E52 which was $5.00 \mathrm{mg}, 2.56 \mathrm{mg}$ and $7.56 \mathrm{mg}$ in saline compared to the control. The concentration of inoculant would have an effect on nitrogen fixation applied to both saline and non saline media [23].

The soaking of the seeds with $\mathrm{N}$-fixing bacteria will produce one of them with high dry weight [24]. Isolates of $\mathrm{N}$-fixing bacteria were able to increase plant biomass because they could produce phytohormones IAA which are growth- promoting hormones in plants [25].

The results of the root dry weight and total biomass given by the isolates of C33 by $2.53 \mathrm{mg}$ and $6.53 \mathrm{mg}, \mathrm{D} 43$ by $2.40 \mathrm{mg}$ and $6.40 \mathrm{mg}$ and E53 by $1.70 \mathrm{mg}$ and $5.70 \mathrm{mg}$ compared to control which is $1.46 \mathrm{mg}$ and $4.6 \mathrm{mg}$ (Table 4). Total biomass represent the overall development of plants towards the shoot or roots. The highest total biomass in isolates that was because these bacteria produce growth hormones, this is in line with the statement of The formation of plant biomass was influenced by the hormones auxin, cytokinin, and abscisic acid (ABA) [26]. Salinity in rice plants results in reduced root length, plant height, crown dry weight, and root weight [27].

\section{CONCLUSION}

Seven of selected isolates (A13, B21, B21, C33, D43, E52, E53) has the ability to form biofilm. The selected of HNR isolates gave the significant effect on roots length, shoot dry weight, roots dry weight and total biomass. Compared to control, the highest roots and total biomass were resulted by the isolates E33, D43 and E53. The total biomass was increased by 41, 39, and $64 \%$, respectively. This results concludes that HNR isolates could use to develops bioagent as biofertlizers to alleviate the salinity stress and to improve the rice growth and productivity of rice on saline soils. 
Vol. 06, No. 06; 2021

ISSN: $2456-8643$

\section{ACKNOWLEDGEMENT}

The authors are grateful for financial support from Academic Leadership Grant (ALG) 2021, Jamtani for facilitating the field technical support and financial support, Universitas Padjadjaran for facilitating the labor analyses and last but not least colleagues who provided insight and expertise that greatly assisted this Research.

\section{REFERENCES}

[1] Louhenapessy, William, et al. "An analysis of the demand for the consumption of rice substitutes in households in the province of Maluku." International Journal of Advanced Engineering Research and Science 5.11, 2018. 268251.

[2] Statistics Indonesia. "Harvested Area, Productivity, and Production of Paddy by Province 2019-2021" 2021.

[3] Mulyani, Anny, et al. "Conversion of Indonesian rice fields as a threat to food security." Jurnal Tanah dan Iklim 40.2, 2016. 121-133.

[4] Simarmata, Tualar, et al. "Improving the Climate Resilience of Rice Farming in Flood-Prone Areas through Azolla Biofertilizer and Saline-Tolerant Varieties." Sustainability 13.21, 2021: 12308.

[5] Purwaningrahayu, R. D., and Taufiq, A. "Mulching and amelioration of saline soil for soybe n growth and yield." Jurnal Agronomi Indonesia Indonesian Journal of Agronomy, 462, 2018. 182-188.

[6] FAO. "Handbook for Saline Soil Management." In FAO. 2018.

[7] Arif, Yamshi, et al. "Salinity induced physiological and biochemical changes in plants: an omic approach towards salt stress tolerance." Plant Physiology and Biochemistry 156, 2020. 6477.

[8] Turan, Murat Ali, et al. "Effect of salt stress on growth, stomatal resistance, proline and chlorophyll concentrations on maize plant." African Journal of Agricultural Research 4.9, 2009. 893-897.

[9] Bamboriya, Sumitra Devi, et al. "Role of biofertilizers in agriculture." 2018.

[10] Sumbul, Aisha, et al. "Azotobacter: A potential bio-fertilizer for soil and plant health management."

Saudi Journal of Biological Sciences 27.12, 2020. 3634.

[11] Shan, L., Yan, Y., Zhan, Y., Ke, X., Shao, Y., Liu, Y., \& Lin, M. “ A Regulatory Network Involving Rpo, Gac and Rsm for Nitrogen-Fixing Biofilm Formation by Pseudemonas stuszeri. Npj Biofilms and Microbiomes, 7(1), 1-15. 2021.

[12] Kanchan, A., Simranjit, K., Ranjan, K., et al. "Microbial biofilm inoculants benefit growth and yield of chrysanthemum varieties under protected cultivation through enhanced nutrient availability." Plant Biosystems-An International Journal Dealing with all Aspects of Plant Biology, 153(2), 306-316. 2019.

[13] Danapriatna, Nana. " Screening of Azotobacter sp and Azospirillum sp from rice field ecosystem as a source of nitrogen fixing biological fertilizer isolates." Jurnal Agrotek Indonesia (Indonesian Journal of Agrotech) 1.2, 2016

[14] O'Toole, G. A. 2011. "Microtiter dish Biofilm formation assay." Journal of Visualized Experiments, (47), 2011. 10-11. 
Vol. 06, No. 06; 2021

ISSN: $2456-8643$

[15] Atlas, R.M., and Parks, L.C. Handbook of Microbiological Media. 2nd ed. Boca Raton: CRC Press. 1997.

[16] Kaburuan, Rahel, et al. "Isolation and characterization of non-symbiotic nitrogen-fixing bacteria in peat soil of Giam Siak Kecil-Bukit Batu Biosphere Reserve." Jurnal agroteknologi 5.1, 2014. 35-39.

[17] Velmourougane, Kulandaivelu, Garima Saxena, at al. "Plant-microbe interactions in the rhizosphere: mechanisms and their ecological benefits." Plant-microbe interactions in agroecological perspectives. Springer, Singapore, 2017. 193-219.

[18] Wang, Yi-Fan, et al. "l-Glutamic acid induced the colonization of high-efficiency nitrogenfixing strain Ac63 Azotobacter chroococcum in roots of Amaranthus tricolor." Plant and Soil 451.1, 2020. 357- 370. Journal, vol. 2, no. 1, 2019, pp. 46-57.

[19] Sriwahyuni, Putu, and Putu Parmila. "Role of Biotechnology." Agricultural Journal, vol. 2, no. 1, 2019, pp. 46-57.

[20] Sutariati, Gusti Ayu Kade, et al. "Study on the potential of plant growth promoting rhizobacteria isolated from healthy rice rhizosphere." Jurnal Agroteknos 4.2. 2014.

[21] Aslam, Muhammad, et al. "Salinity stress in crop plants: effects of stress, tolerance mechanisms and breeding strategies for improvement." J Agric Basic Sci 2.1, 2017. 70-85.

[22] Prayoga, Muhamad Khais, et al. "Climate field schools to increase farmers' adaptive capacity to climate change in the southern coastline of Java." Open Agriculture 6.1, 2021 192201.

[23] Kusrachdiyanti, N. M., et al. "Isolatic Rhizobactery and Isolative Nitrogen Testing as Growth Extractor at Saline Soils Ecosystems." Jurnal Ilmiah Pertanian, vol. 16, no. 2, 2020, pp. $116-25$.

[24] Setiawati, Mieke Rochimi, et al. "Application of Nitrogen-fixing endophytic bacteria to increase endophytic bacteria population and rice crop yield." Agrikultura, vol. 19, no. 3, 2008, doi:10.24198/agrikultura.v19i3.1009.

[25] Dewi, Alin Kusumah, and Mieke Rochimi Setiawati. "Effect of endophytic biological fertilizer with azolla pinnata on $\mathrm{n}$ absorption, $\mathrm{n}$-total soil, and dry weight of oryza sativa 1. rice plants in saline soil." Agrologia, vol. 6, no. 2, 2018, doi:10.30598/a.v6i2.168.

[26] Albacete, A. Hormonal Changes in Relation to Biomass Partitioning and Shoot Growth Impairment In Salinized Tomato (Solanum lycopersicum L.) Plants. Journal of Experimental Botany, 2008. 594119-4131

[27] Suhartini, T. and T. J. P. Hardjosudarmo. Tolerance of local rice germplasm to salinity. Bul. Plasma Nutfah, 2017. 23(1): 51-58. 